Article

\title{
Adopters versus Non-Adopters of the Green Key Ecolabel in the Dutch Accommodation Sector
}

\author{
Eelco Buunk ${ }^{1}$ and Edwin van der Werf ${ }^{2, *}$ \\ 1 KplusV, P.O. Box 60055, 6800 JB Arnhem, The Netherlands \\ 2 Environmental Economics and Natural Resources Group, Wageningen University, P.O. Box 8130, \\ 6700 EW Wageningen, The Netherlands \\ * Correspondence: edwin.vanderwerf@wur.nl; Tel.: +31-3174-83318
}

Received: 3 May 2019; Accepted: 24 June 2019; Published: 28 June 2019

\begin{abstract}
Accommodation providers such as hotels, campsites, and holiday villages can use ecolabels to show their green credentials to potential customers. Whereas there is extensive literature on ecolabel adoption in the Hotel and Bed and Breakfast (B \& B) sector, no such research exists for other accommodation sectors. In this paper, we present the results of statistical analyses of survey data from firms in the Dutch accommodation sector (including hotels, campsites, and group accommodations) with and without the Green Key ecolabel, which is a third-party certified international label for the tourist and leisure sector. We obtain insights into the motivations for adopting (or not), analyze the characteristics of firms with and without the label, and get an indication of the perceived impact of ecolabel adoption on costs and profits. We find that previously found results for hotels and B \& Bs do not always apply to other subsectors of the accommodation sector. We also find that obtaining the label required a limited investment for almost half of the sample, and resulted in cost reductions for more than half of the responding firms.
\end{abstract}

Keywords: ecolabel; sustainable tourism; certification; hotel management; campsites; ecolabel adoption

\section{Introduction}

Accommodation providers, such as hotels and campsites, impact the environment in various ways, including water and energy use, impact on the landscape, and disposal of waste and wastewater [1-3]. While companies in the accommodation sector increasingly voluntarily implement sustainable business practices, such 'green' production processes may be more costly than conventional ones [4-8]. Furthermore, since green goods are credence goods [9], consumers are not able to recognize environmental attributes when purchasing the product. Ecolabels can help reduce this information asymmetry. When a firm applies for a third-party certified ecolabel, a verifying body assesses the firm. If it passes the test, the firm receives a label that allows it to communicate to customers that it is green according to the standards set by the labeling organization $[10,11]$. Hence, ecolabels reduce consumers' costs for searching for information about product characteristics [12]. Although green products may be more costly to produce, green customers may be willing to pay a price premium over the price of 'brown' conventionally produced goods (e.g., $[13,14])$. If adopting firms turn from the provision of brown goods to green goods or if consumers switch from brown to green goods after observing an ecolabel, ecolabels may help reduce environmental impacts. Ecolabels are, as a (voluntary) policy instrument, especially relevant for sectors that are subject to little environmental regulation from public authorities, such as the tourism sector [15]. Buckley ([4], pp. 187-192) provides a great description of the rise and development of ecolabels in tourism. 
The aims of this paper are (1) to assess the motivations for firms in the Dutch accommodation sector (not) to adopt an ecolabel; (2) to assess how labeled firms perceive the effect of adoption of the Green Key label on profits and costs, and what investments were required; and (3) to analyze the differences between firms with and without the ecolabel in terms of firm characteristics, market conditions, and perceptions of ecolabels. We present results from survey data on the motivation of firms in the Dutch accommodation sector to adopt or not to adopt the Green Key ecolabel and analyze the characteristics of firms that did (not) adopt the label. The Green Key ecolabel is a third-party certified international label that is used in the tourist and leisure sector to show that companies make more effort than required by law to be environmentally sustainable. We contribute to the existing literature on ecolabel adoption in the accommodation sector in three ways. First, while the existing literature focuses on hotels and Bed and Breakfasts (B \& Bs, e.g., [5,12,16]), our study is the first to analyze ecolabel adoption by campsites and holiday villages as well. Second, most of the literature on ecolabels in the accommodation sector uses qualitative methods and small samples (e.g., [5,8,16]), or only studies labeled [17] or unlabeled firms [18]. We present statistical evidence based on survey data from more than 200 firms and analyze how firms with and without the label differ in the Dutch accommodation sector at large as well as in each of the subsectors. We not only present results from statistical tests for the distribution of the variables, but also analyze whether results from these tests still hold in multiple regression analyses. Third, we present initial quantitative evidence on the perceived impacts of ecolabel adoption on costs and profits.

The case study of our analysis is the Green Key ecolabel, which is an international label that is used in the tourist and leisure sector to show that companies make more effort than required by law to be environmentally sustainable [19]. The Green Key label is issued by a non-profit non-governmental organization, and can be adopted voluntarily. Green Key International started as a Danish initiative in 1994 and was adopted by the Foundation for Environmental Education (FEE) in 2002, making it an internationally recognized label $[20,21]$. The Dutch branch of Green Key has its origin in the 'Milieubarometer' (Environmental Barometer). This label started in 1998 as an initiative from businesses in the recreational and tourist industry. In 2003, a European cooperative started between different labels, resulting in the merger of these labels. In 2007, the name 'Milieubarometer' changed to 'Green Key'. With this change, the international Green Key guidelines replaced the original guidelines, but because the Milieubarometer had stricter guidelines than Green Key, the Dutch Green Key guidelines were adapted to these. Hence, the Dutch branch of Green Key has different, stricter, standards than the international ones. Guests should be unaware of the environmental measures taken, in the sense that comfort levels should not be negatively affected.

The entrance fee is $€ 195$, which covers the costs of verification. The annual fee depends on annual turnover; the maximum rate is $€ 725$ for companies with a turnover of at least $€ 1.2$ million. Verification is done by a third party: Groen Belicht. The criteria and standards comprise 13 categories, such as water, waste, and energy [22]. The requirements for each category differ per subsector, e.g., hotels and campsites have different requirements within the same category. There are obligatory norms for obtaining the label, which is indicated as the 'Bronze' label, that include water-saving norms for showers and toilets, bans on single-service packages, and serving coffee and tea from sustainable brands. In addition, there are 'Silver' and 'Gold' labels. If a firm meets at least $52 \%$ of the optional norms, it can obtain the 'Gold' label. Optional norms range from the use of ecolabeled cleaning products to installation of Combined Heat and Power units for electricity and heat generation. In this paper, we do not differentiate between the different categories.

We focused on firms in the accommodation sector as defined by SBI-code I-55 of the Dutch Chamber of Commerce. We focus our study on the subsectors hotels, conference centres, campsites, holiday villages, group accommodations, natural campsites, mini campsites, and B \& Bs, and excluded about 50 companies from subsectors as diverse as 'restaurants', 'public swimming and indoor halls', 'passenger transport by boat', and 'outdoor sports' that are clearly distinct from the accommodation sector. Holiday villages consist of a few dozen up to a few hundred houses with one or more bedrooms, 
and typically cater to families and offer swimming and dining facilities. For our analysis, 'hotel' and 'B \& B' were combined into one group, as were 'campsite', 'natural campsite', and 'mini-campsite' (into 'Campsite'), as were 'holiday villages' and 'group accommodations' (into 'Holiday villages and group accommodations'). The group 'Conference centres' largely consists of conference centres and other activity centers (music and theatre). Some hotels that were classified in the first group offer conference rooms as well.

We find that results for the hotel and B \& B sector are not necessarily representative for the accommodation sector as a whole. For example, we find that labeled hotels and B \& Bs are larger than their unlabeled counterparts, but we find mixed results for campsites and holiday villages. Whereas statistical tests show that labeled firms tend to agree more than unlabeled firms with the statement that consumers are confident that the information conveyed by ecolabels is reliable, this result disappears in all of our multiple regression models. Regarding profits and costs: while more than half of responding firms with a Green Key label reported a reduction in variable costs after adoption of the label, only $26 \%$ reported an increase in profits. Interestingly, almost $40 \%$ of responding firms had to make investments of $€ 500$ or less to obtain the label.

The remainder of this paper is organized as follows. In the next section, we present a survey of the literature and key items of our survey. In Section 3, we introduce the Green Key ecolabel and describe the sampling and data collection procedures. In Section 4, we first present results on the motivations of firms for adopting the Green Key label and present reported changes in profits and the costs of labeled firms. We then analyze characteristics of firms with and without the label for the Dutch accommodation sector as a whole and for the various subsectors. We also use a probit model to test whether these results still hold in a multiple regression model of ecolabel adoption and assess how the probability of being labeled is affected by firm characteristics. In Section 5, we discuss our results, and we conclude in Section 6.

\section{Literature and Key Survey Items}

In this section, we review the literature on the adoption of ecolabels in the accommodation sector to identify the key variables needed in our empirical assessment of ecolabel adoption in the Dutch accommodation sector. Since the literature on ecolabels is rather limited, we also include literature on the adoption of environmental management systems (EMSs). We follow Ayuso ([23], p. 209) and define an EMS as having the aim to "manage the environmental performance of the company and improve it continuously according to a planned strategy", whereas the aim of an ecolabel is to "ensure the environmental performance of the company with regard to certain aspects, and offer the corresponding information to the consumer". Hence, ecolabels are more consumer-oriented than EMSs.

\subsection{Motivations for Adoption}

Economic theory suggests that eco-label adoption allows 'green' producers to demand a higher price than their 'brown' competitors, which is needed because of the higher costs of production when using sustainable production processes [24]. However, Rivera [12] did not find evidence that the hotels that participate in the Costa Rican Certification for Sustainable Tourism program were able to demand higher prices. Indeed, possession of an ecolabel does not seem to lead to increased sales for hotels and B \& Bs $[12,16]$. Motivations for an ecolabel can largely be grouped into two categories: business benefits and green philosophy. Tzschentke et al. [8] interviewed 30 owner-managers of small hotels and B \& Bs that were members of the Green Tourism Business Scheme (GTBS), and found that the decision to join the GTBS was based on "the prospect of commercial benefits, the knowledge that joining required little or no change to current practices, and the fact that the principles of the scheme were ones the owner-manager endorsed" (p. 120). Based on interviews with 30 managing directors of Spanish hotels, Ayuso [15] found that hotels that adopt an ecolabel have a history of environmental practices, and do not have to make big investments to get certified. Duglio et al. [17] found that personal awareness of the sustainability issue and improving the corporate image were the main motivation for adoption of the 
European ecolabel by Italian accommodation establishments. Dunk et al. [5] asked 109 members and former members of the GTBS in Scotland about their reasons and expectations for joining. Allowing for multiple answers, $63 \%$ gave 'green philosophy and practice' as a reason for joining. With $58 \%$, the group indicating 'business benefits' as one of the reasons was not much smaller.

The literature on EMSs confirms the (mixed) results for ecolabels. Implementation of an EMS seems to lead to cost savings rather than cost increases in the hotel sector, often with little investment. Geerts [6] found that 17 out of 21 interviewed managers of London hotels had implemented sustainable business practices to save costs, whereas less than half of the respondents implemented them for environmental motivations. Ayuso [15] found that envisioned cost savings are one of the main motivations for initiating environmental practices (including both ecolabels and EMSs), yet more than half of the respondents also mentioned personal awareness, and EMS adoption is rather motivated by a feeling of getting recognized for the efforts by a third party.

Garay and Font [25] found that economic motivations are only secondary to altruistic reasons such as environmental protection in their analysis of (mostly small) hotels in Catalunya. Ayuso [15] found that an EMS does not seem to lead to increased sales for hotels and B \& Bs.

Adoption of an ecolabel usually comes with certification costs. In addition to the monetary costs of certification, assessment by the certification agency is a time-consuming process. These costs can induce managers not to adopt the ecolabel, despite meeting the label's standards [15].

In the survey, we asked respondents about their motivation (not) to adopt an ecolabel. We also asked certified firms about the investments they had to make and the resulting cost savings and change in profits.

\subsection{Differences in Characteristics of Firms with and without an Environmental Management Tool}

The tourism literature suggests that firms (in this literature: hotels and B \& Bs) with an EMS can differ from their uncertified competitors along various dimensions. Obtaining certification is a costly and time-consuming process that may be too costly for small firms $[6,23,26]$. Larger firms may have higher awareness and more resources to undertake the process of implementation and adoption $[6,27,28]$. Segarra-Oña et al. [7] found that hotels in Spain with an ISO 14001 certificate are generally larger than hotels without. Since hotels that belong to a chain can use a central management unit for the certification process, having multiple establishments may matter [23,29,30]. Ayuso [15] found that the involvement of hotel management and staff is a critical factor for the implementation of an EMS in Spanish hotels, which suggests that the larger the number of employees, or the larger the number of organisational layers in the firm, the harder it becomes to implement an EMS.

In addition to size, age might be a firm characteristic that is relevant for ecolabel adoption: younger firms may be more willing to adopt new business practices than older firms. Indeed, based on the sustainable entrepreneurship literature, Hockerts and Wüstenhagen ([31], p. 481) argued that "in the early stages of an industry's transformation towards sustainability, it is typically small firms and new entrants that stimulate disruptive sustainability innovation".

Segarra-Oña et al. [7] reported that the share of Spanish hotels with ISO14001 certification is higher for rural hotels than for city hotels.

As noted above, green philosophy can be a motivation to adopt an ecolabel or EMS. Sampaio et al. [16] found that the environmental preferences of the owners or managers matter for the adoption of the GTBS label, while Ayuso [23] found the same for the adoption of environmental practices (including both ecolabels and EMSs).

We asked our respondents about the age of their firm, its size, whether it had multiple establishments, its location (rural or urban), and to what extent sustainability is important for their company. 


\subsection{Market Conditions}

The adoption of an ecolabel allows a firm to differentiate itself from its competitors. The opportunity for a firm to do so will depend on the characteristics of the market in which it operates. Geerts [6] interviewed 21 managers of hotels in London that had joined a certification scheme (although not necessarily one that is third-party certified) and concluded that price, location, and quality appeared to be more important for guests when booking a hotel than certifications. Hence, we asked respondents to what extent they think that customers value sustainability, and whether firms in the sector compete on price, quality, or green image.

Ecolabel adoption can be viewed as the diffusion of a new technology in a sector, which is a gradual process [32]. Firms would like to have information about the new technology before adopting it, and can acquire this information from early adopters in their sector. As a consequence, adoption might differ between subsectors (hotels, holiday villages, campsites), also because of differences in sector-specific characteristics (including technologies and costs to meet the requirements of the label) and regulation. A firm's probability to be certified will also be affected by the behavior of their competitors [33]. Therefore, we asked firms in which subsector they operate, to what extent they agree with the statement "many competitors have an ecolabel", and for an estimate of the percentage of competitors with an ecolabel.

\subsection{Perceptions of Ecolabels}

Ecolabels can signal to consumers that the labeled firm uses 'green' production technologies and allow their holders to show to customers that their environmental efforts are real and genuine rather than 'greenwash'. Chen and Chang [34] analyzed the relation between greenwash and consumers' green trust in electronics products in Taiwan, and found that greenwash is positively related to consumer confusion. Consumer attitudes toward ecolabels matter, as an ecolabel should be understood and trusted by consumers $[11,35,36]$. Hence, adopting firms may be more confident that consumers trust ecolabels than unlabeled competitors. Still, several studies reported that hotel managers argue that customers are unfamiliar with or sceptical toward certification schemes, possibly because there are so many of them $[18,37,38]$. We asked respondents to what extent they agree with the statement, "Consumers are confident that the information conveyed by ecolabels is reliable". We also asked respondents to what extent they agree with the statement "Consumers understand the meaning of ecolabels".

Following the same reasoning, firms' trust in the label is equally important. Firms will only invest in costly certification if they think that the label successfully separates sustainable from unsustainable firms: the higher the perceived accuracy of the certification procedure, the fewer unsustainable firms will apply and pay for certification [24]. Therefore, we asked firms about their perceptions of the assessment of ecolabeled firms.

\section{Research Questions, Case Study, Sampling, and Data Collection}

\subsection{Research Questions and Hypotheses}

The aim of the paper is to analyze differences between firms in the Dutch accommodation sector that did and did not adopt the Green Key ecolabel. To that purpose, we formulated the following research questions: (1) What are the motivations for firms in the Dutch accommodation sector (not) to adopt an ecolabel? (2) How do labeled firms perceive the effect of adoption of the Green Key label on profits and costs, and what investments were required? (3) What are the differences between firms with and without the ecolabel in terms of firm characteristics, market conditions, and perceptions of ecolabels? Regarding the latter, we have the following hypotheses based on the discussion of the literature in Section 2:

- a positive correlation between firm size and ecolabel adoption; 
- a negative correlation between age and ecolabel adoption;

- a positive correlation between being located in a rural area and ecolabel adoption;

- a positive correlation between firms' views on sustainability and ecolabel adoption;

- a positive correlation between firms' views on consumers valuation of sustainability and ecolabel adoption;

- a positive correlation between the (perceived) number of labeled competitors and ecolabel adoption;

- a positive correlation between firms' views on consumers perceptions about ecolabels and ecolabel adoption;

- $\quad$ and a positive correlation between firms' own perceptions of ecolabels and ecolabel adoption.

\subsection{Sampling and Data Collection}

A list of all the Dutch Green Key labeled companies can be found on the website of Green Key Netherlands [39]. We first contacted companies with multiple references (e.g., hotels belonging to a chain) to check whether it was centrally decided to adopt the label or if they had decided to adopt it independently. Our final list—of Green Key labeled firms that had either independently adopted the Green Key label or adopted it through the chain's central management-consisted of 270 firms. The unlabeled companies were selected from the website of the Dutch Chamber of Commerce [40]. A database was created, including all the companies within the accommodation sector in the Netherlands (SBI-code I-55), except for the about 50 firms mentioned above. Additionally, the following characteristics were selected: the results had to be business enterprises that were still economically active and were the main office within that enterprise. This resulted in 6622 different potential observations, which were arranged by their Chamber of Commerce registration number. From this list, 650 unique random numbers were drawn, and the corresponding firms were selected. When a firm either had a Green Key label or did not have an email address, the next firm on the list was selected. For each selected unlabeled firm, it was checked whether it was part of a franchise organization or chain.

The final database consisted of 918 companies, of which 270 had a Green Key ecolabel and 648 did not. All the firms were approached via email for an online survey, for which we used the web-based tool Qualtrics. After one week, a first reminder was sent to each firm that had not completed the questionnaire by then, and another week later, a second reminder was sent. In total, 206 unique respondents started the questionnaire and at least indicated whether they had a Green Key label, of which 89 had the Green Key label and 117 had no ecolabel. Unfortunately, not all the questionnaires were fully completed, and hence, the number of observations differs per variable. More information on the questions used in the survey and the number of responses per question can be found in Appendix A.

We tested whether our sample of responding firms is representative for the sample of the firms that we contacted using the sector in which the firm operated and the province where the firm is located (the only variables for which we have information for both samples). We were not able to reject the null hypothesis ( $5 \%$ significance level) that the proportions in the sample of responding firms were equal to the proportions in the sample of firms contacted, for both the labeled and unlabeled firms.

The questionnaire included questions covering the key variables identified in the literature (see Section 2). Descriptive statistics can be found in Table A1 in Appendix A.

\section{Results}

\subsection{Motivations for Adopting or Not Adopting}

We asked firms for their main motivation for (not) adopting the Green Key ecolabel. Respondents could only mention one reason. As can be seen in Table 1, the two main reasons for labeled firms to adopt the Green Key label were "better for the environment" and "good for the image of the company". Interestingly, "it increases profits" was mentioned only once, and differentiation from competitors was also mentioned far less often than the first two reasons. 
Table 1. Frequency distribution of reasons for Green Key labeled firms for adopting the label.

\begin{tabular}{cc}
\hline Reason for Being Labeled & Frequency \\
\hline Better for the environment & 23 \\
Good for the image of the company & 23 \\
To differentiate within the sector & 9 \\
It increases profits & 1 \\
The competition has a label as well & 1 \\
Other & 13 \\
Missing & 19 \\
Total & 70 \\
\hline
\end{tabular}

We not only asked labeled firms for their motivations to adopt an ecolabel; we also asked unlabeled firms why they had not adopted an ecolabel. Table 2 shows that almost one-third of responding firms did not deem it necessary to have an ecolabel in order to be sustainable. A large group of firms mentioned costs as a reason not to adopt an ecolabel: 20 firms indicated that the investments to be made in order to comply with the standards would be too large, while eight firms indicated that certification costs are too high. Only two firms thought that their variable costs would increase after adoption of the label. A lack of demand for environmentally sustainable services was mentioned by nine firms.

Table 2. Frequency distribution of reasons for unlabeled firms for not adopting an ecolabel.

\begin{tabular}{cc}
\hline Reason for Not Being Labeled & Frequency \\
\hline It is not necessary to have an ecolabel in order to be sustainable & 32 \\
The investments that have to be made in order to comply with the standards are too large & 20 \\
There is not enough demand for environmentally sustainable services in my sector & 9 \\
The certification costs are too high & 8 \\
The variable costs would increase & 2 \\
I can ask a lower price than my competitors & 1 \\
Other & 26 \\
Missing & 19 \\
Total & 98 \\
\hline
\end{tabular}

\subsection{Labeled Firms: Profits and Costs}

We found that, of the 68 Green Key labeled firms that responded to the question of whether their profits had increased due to adoption of the ecolabel, $26 \%$ stated that their company had become more profitable after adoption, but only $4 \%$ reported that they were able to increase their price. This suggests that the profit increase resulted from a decrease in costs. Indeed, while $10 \%$ of responding labeled firms reported an increase in variable costs after adoption of the label, 58\% reported a decrease in variable costs $(\mathrm{N}=71)$. Of the 43 firms reporting a percentage change in variable costs after adoption of the label, five reported an increase, and 15 reported a decrease. The mean change in variable costs was $-3.2 \%$ (t-stat. -2.55$)$, where we excluded one observation where a $100 \%$ reduction was reported, which we deemed unrealistic. Of the 18 labeled companies reporting an increase in profits, 15 stated that this was due to lower variable costs, whereas three reported that this was due to a higher price.

In our sample, of all the labeled firms that reported on fixed adjustment costs $(N=56), 18 \%$ reported zero adjustment cost, and $21 \%$ reported positive investment costs of $€ 500$ or less. Still, mean investment costs were $€ 17.634$, the median was $€ 3.000$ and the maximum reported investment was $€ 350.000$, suggesting that while a substantial fraction of firms that adopted the Green Key ecolabel had zero or little adjustment costs to fulfill the criteria, this is not a general rule for adopting firms. 


\subsection{Differences between Labeled and Unlabeled Firms}

In this section, we present the results of statistical tests in which we compared firms with the Green Key ecolabel against firms without an ecolabel. Depending on the structure of the underlying data, we reported results for Mann-Whitney, Fisher's exact, and Pearson's Chi-squared tests.

\subsubsection{Firm Characteristics}

We asked firms with and without the Green Key ecolabel about the size of their firm, and did so for various dimensions: number of full-time equivalent (FTE) employees, revenues (in five categories, ranging from less than $€ 100,000$ to more than $€ 5,000,000)$, and whether the firm had multiple establishments. The results in Table 3 show that for all three variables, the null hypothesis (either equal distribution for labeled and unlabeled firms or that the proxy for size is independent of being labeled) is rejected. Inspection of the relative frequency distributions shows that in all cases, the distribution for labeled firms is shifted to the right. Labeled firms tend to have more employees (the mean is 21.3 FTE for firms with the Green Key label and 3.7 for unlabeled firms), and more revenues than unlabeled firms. This suggests that larger firms are more able to bear the monetary and non-monetary costs of ecolabel adoption than smaller firms. Labeled firms also tend to have more establishments than unlabeled firms (means: 1.35 and 1.03 respectively). Labeled firms are also older (means: 36 and 26 years, respectively).

Table 3. Labeled vs. unlabeled firms: firm characteristics. FTE: full-time equivalent.

\begin{tabular}{cccc}
\hline Variable & Hypothesis & Test Result & N \\
\hline Employees (FTE) & Same distribution labeled and unlabeled firms & $\mathrm{z}=4.33^{* * *}$ & 97 \\
\hline Revenues (five categories) & Revenues independent of being labeled & $p=0.00^{* * *}$ & 119 \\
\hline Multiple establishments & Having multiple establishments independent of \\
being labeled & $p=0.02^{* *}$ & 206 \\
\hline Age & Same distribution labeled and unlabeled firms & $\mathrm{z}=2.48^{* *}$ & 204 \\
\hline $\begin{array}{c}\text { Sustainability important for } \\
\text { company (five categories) }\end{array}$ & Response to statement in-dependent of being labeled & $p=0.00^{* * *}$ & 151 \\
\hline Urban & Urban yes/no independent of being labeled & $p=0.02 * *$ & 191 \\
\hline & $* * * * * *$ indicates statistically significant at the 10/5/1\% level. & &
\end{tabular}

We asked respondents to what extent (five-point Likert scale, ranging from 'Strongly agree' to 'Strongly disagree') they agreed with the statement '[company name] has the opinion that sustainability is important'. Labeled firms tended to agree more strongly with this statement than firms without a label. Unfortunately, we could not assess whether this was a reason for adoption, or this was a result of adoption (for example, through increased environmental awareness).

The final firm characteristic concerns the location of the firm for firms with only one establishment $(\mathrm{N}=191)$. Firms with the Green Key ecolabel tend to be more often located in urban areas than unlabeled firms.

Table 4 shows the results by subsector. Hotels and B \& Bs with the Green Key label tend to be larger than unlabeled competitors along all the dimensions. In all the subsectors, labeled companies tend to have more revenues than unlabeled firms. Labeled holiday villages and group accommodations also tend to have more employees. The number of establishments appears to be larger for labeled firms only in the Hotel and B \& B sector. 
Table 4. Labeled vs. unlabeled firms: firm characteristics by subsector.

\begin{tabular}{ccccc}
\hline Variable & Hotels and B \& Bs & Campsites & $\begin{array}{c}\text { Holiday Villages and } \\
\text { Group Accommodations }\end{array}$ & $\begin{array}{c}\text { Conference } \\
\text { Centers }\end{array}$ \\
\hline Employees (FTE) & $\mathrm{z}=3.39^{* * *}(36)$ & $\mathrm{z}=1.29(32)$ & $\mathrm{z}=1.85^{*}(15)$ & $\mathrm{z}=1.61(13)$ \\
\hline $\begin{array}{c}\text { Revenues (five } \\
\text { categories) }\end{array}$ & $p=0.01^{* * *}(43)$ & $p=0.08^{*}(42)$ & $p=0.03^{* *}(19)$ & $p=0.02^{* *}(15)$ \\
\hline $\begin{array}{c}\text { Number of } \\
\text { establishments }\end{array}$ & $p=0.01^{* * *}(76)$ & $p=0.39(62)$ & $p=0.56(36)$ & $p=0.69(31)$ \\
\hline Age & $\mathrm{z}=0.84^{(75)}$ & $\mathrm{z}=2.17^{* *}(62)$ & $\mathrm{z}=1.98^{* *}(36)$ & $\mathrm{z}=2.03^{* *}(30)$ \\
\hline $\begin{array}{c}\text { Sustainability } \\
\text { important for company } \\
\text { five categories) }\end{array}$ & $p=0.00^{* * *}(57)$ & $p=0.04^{* *}(46)$ & $p=0.07^{*}(25)$ & $p=0.40(22)$ \\
\hline Urban & $p=0.02^{* *}(68)$ & $-{ }^{a}(61)$ & $-{ }^{a}(35)$ & $p=0.13(26)$ \\
\hline
\end{tabular}

${ }^{* * * * * * *}$ indicates statistically significant at the $10 / 5 / 1 \%$ level. Number of observations in parentheses. ${ }^{a}$ All the campsites and holiday villages and group accommodations reported to be located in a rural environment.

Interestingly, the age distribution of firms does not differ for labeled and unlabeled hotels and B \& Bs, while labeled firms tend to be older in all the other subsectors.

Whereas labeled and unlabeled conference centers do not seem to differ in their response to the statement '[company name] is of the opinion that sustainability is important', labeled firms in the other subsectors tend to agree more strongly with this statement than unlabeled firms. It should be noted that the number of observations is smallest for the former group.

Labeled hotels and B \& Bs were more likely to be located in urban areas than their unlabeled competitors. Zero campsites, holiday villages, and group accommodations (both labeled and unlabeled) were located in urban areas.

\subsubsection{Market Conditions}

Market conditions may affect the willingness of a firm to adopt an ecolabel. We asked firms to what extent they agree with the statement 'Customers value sustainability', using a five-point Likert scale. As shown in Table 5, firms with the Green Key ecolabel tended to agree more strongly with the statement than unlabeled firms.

Table 5. Labeled vs. unlabeled firms: Market conditions.

\begin{tabular}{|c|c|c|c|}
\hline Variable & Hypothesis & Test Result & $\mathbf{N}$ \\
\hline $\begin{array}{l}\text { Customers value sustainability (five } \\
\text { categories) }\end{array}$ & $\begin{array}{c}\text { Response to statement } \\
\text { independent of being labeled }\end{array}$ & $p=0.02^{* *}$ & 149 \\
\hline Competition focuses on price & $\begin{array}{c}\text { Same distribution labeled and } \\
\text { unlabeled firms }\end{array}$ & $p=0.28$ & 150 \\
\hline Competition focuses on green image & $\begin{array}{c}\text { Same distribution labeled and } \\
\text { unlabeled firms }\end{array}$ & $p=0.52$ & 150 \\
\hline $\begin{array}{l}\text { Many competitors have an ecolabel } \\
\text { (five categories) }\end{array}$ & $\begin{array}{l}\text { Response to statement } \\
\text { independent of being labeled }\end{array}$ & $p=0.00^{* * *}$ & 148 \\
\hline $\begin{array}{l}\text { Percentage of competitors that have } \\
\text { an ecolabel }\end{array}$ & $\begin{array}{l}\text { Same distribution of labeled } \\
\text { and unlabeled firms }\end{array}$ & $\mathrm{z}=6.43^{* * *}$ & 122 \\
\hline
\end{tabular}

Next, we asked respondents about the main item of competition in the sector: price, quality, green image, or 'other'. There was not a statistically significant difference between the two groups of firms for any of the items. Interestingly, even though it does not seem that labeled firms operate in an environment in which competition focuses on having a green image, labeled firms tended to agree 
more strongly with the statement 'Many of my competitors have an ecolabel' than unlabeled firms, and they tend to report a higher number for the percentage of competitors that has an ecolabel.

Table 6 presents the results on market conditions by subsector. At the subsector level, the result that labeled firms tended to agree more strongly with the statement that customers value sustainability was only confirmed for hotels and B \& Bs. This was probably partly driven by the small sample sizes for the other subsectors. The absence of a statistically significant difference in the perception of the focus point of competition also shows up at the level of the subsectors.

Table 6. Labeled vs. unlabeled firms: market conditions by subsector.

\begin{tabular}{ccccc}
\hline Variable & Hotels and B \& Bs & Campsites & $\begin{array}{c}\text { Holiday Villages and } \\
\text { Group Accommodations }\end{array}$ & $\begin{array}{c}\text { Conference } \\
\text { Centres }\end{array}$ \\
\hline $\begin{array}{c}\text { Customers value } \\
\text { sustainability } \\
\text { (five categories) }\end{array}$ & $p=0.10^{*}(57)$ & $p=0.79(47)$ & $p=1.00(25)$ & $p=0.58(19)$ \\
\hline $\begin{array}{c}\text { Competition focuses } \\
\text { on price }\end{array}$ & $p=0.45(56)$ & $p=0.29(47)$ & $p=0.30(24)$ & $p=0.37(22)$ \\
\hline $\begin{array}{c}\text { Competition focuses on } \\
\text { green image }\end{array}$ & $p=0.71(56)$ & $p=0.36(47)$ & $p=0.54(24)$ & $p=0.82(22)$ \\
\hline $\begin{array}{c}\text { Many competitors have an } \\
\text { ecolabel (five categories) }\end{array}$ & $p=0.00^{* * *(53)}$ & $p=0.08 *(47)$ & $p=0.42(25)$ & $p=0.02 * *(22)$ \\
\hline $\begin{array}{c}\text { Percentage of competitors } \\
\text { that have an ecolabel }\end{array}$ & $\mathrm{z}=3.59 * * *(45)$ & $\mathrm{z}=1.22(36)$ & $\mathrm{z}=3.05 * * *(21)$ & $\mathrm{z}=2.71 * * *(20)$ \\
\hline
\end{tabular}

$* / * * * * *$ indicates statistically significant at the $10 / 5 / 1 \%$ level. Number of observations in parentheses.

In all the subsectors except for holiday villages and group accommodations, labeled firms tended to agree more strongly with the statement that many competitors have an ecolabel than unlabeled firms. However, when it comes to the reported number of competitors with an ecolabel, campsites were the only sector in which labeled firms did not report a statistically significant higher number for the percentage of competitors that had an ecolabel than unlabeled firms.

\subsubsection{Perceptions of Ecolabels}

The results in Table 7 show that the two groups of firms did not differ in their response to the statement 'Consumers understand the meaning of ecolabels'. Interestingly, not a single firm responded 'strongly agree', and for both groups of firms, a large share responded with 'disagree' or 'strongly disagree'. Firms with the Green Key ecolabel tended to agree more strongly with the statement 'Consumers are confident that the information conveyed by ecolabels is reliable' than unlabeled firms. It should be noted that the opinion of labeled firms may have been formed after adoption of the Green Key label.

Table 7. Labeled vs. unlabeled firms: perceptions of ecolabels.

\begin{tabular}{cccc}
\hline Variable & Hypothesis & Test Result & N \\
\hline $\begin{array}{c}\text { Consumers understand the meaning } \\
\text { of ecolabels (five categories) }\end{array}$ & $\begin{array}{c}\text { Response to statement } \\
\text { independent of being labeled }\end{array}$ & $p=0.29$ & 145 \\
\hline $\begin{array}{c}\text { Consumers are confident that the } \\
\text { information conveyed by ecolabels } \\
\text { is reliable (five categories) }\end{array}$ & $\begin{array}{c}\text { Response to statement } \\
\text { independent of being labeled }\end{array}$ & $p=0.07^{*}$ & 146 \\
\hline $\begin{array}{c}\text { There is sufficient assessment of } \\
\text { compliance of labeled firms with } \\
\text { ecolabel's rules (five categories) }\end{array}$ & $\begin{array}{c}\text { Response to statement } \\
\text { independent of being labeled }\end{array}$ & $p=0.00^{* * *}$ & 147 \\
\hline & $* * * * *$ indicates statistically significant at the 10/5/1\% level. &
\end{tabular}


Green firms may be more willing to adopt an ecolabel when they trust its assessment procedure, while brown firms may be less likely to adopt a label when there is sufficient assessment of compliance. Green Key-labeled firms tended to agree more strongly with the statement 'There is sufficient assessment of compliance of labeled firms with ecolabel's rules' than unlabeled firms. However, whether this was already the case before adoption, or labeled firms became confident due to their experience with the Green Key assessment procedure is not clear.

When we analyzed the responses at the level of subsectors (Table 8), some interesting results appeared. Hotels and B \& Bs seemed to be the only sector in which labeled firms tended to agree more strongly with the statement that consumers are confident that the information conveyed by ecolabels is reliable. While for the 'Holiday villages and group accommodations' and 'Conference center' groups, this may have been caused by the relatively small subsamples, the result for Campsites was rather striking, as not only was the sample rather large, the p-value of the Fisher Exact test was also very high. Whereas two unlabeled firms strongly agreed with the statement, zero labeled firms did.

Table 8. Labeled vs. unlabeled firms: perceptions of ecolabels by subsector. ${ }^{a}$

\begin{tabular}{ccccc}
\hline Variable & Hotels and B \& Bs & Campsites & $\begin{array}{c}\text { Holiday Villages and } \\
\text { Group Accommodations }\end{array}$ & $\begin{array}{c}\text { Conference } \\
\text { Centers }\end{array}$ \\
\hline $\begin{array}{c}\text { Consumers are confident } \\
\text { that the information } \\
\text { conveyed by ecolabels is } \\
\text { reliable (five categories) }\end{array}$ & $p=0.05^{*}(54)$ & $p=0.80(45)$ & $p=0.33(25)$ & $p=0.59(21)$ \\
\hline $\begin{array}{c}\text { Consumers understand the } \\
\text { meaning of ecolabels (five } \\
\text { categories) }\end{array}$ & $p=0.36(52)$ & $p=0.54(47)$ & $p=0.75(25)$ & $p=0.21(21)$ \\
\hline $\begin{array}{c}\text { There is sufficient } \\
\text { assessment of compliance of } \\
\text { labeled firms with ecolabel's } \\
\text { rules (five categories) }\end{array}$ & $p=0.00^{* * *}(54)$ & $p=0.00 * * *(46)$ & $p=0.00^{* * *}(25)$ & $p=0.79(22)$ \\
\hline ****** indicates statistically significant at the $10 / 5 / 1 \%$ level. Number of observations in parentheses.
\end{tabular}

Table 7 shows that there was no statistically significant difference between the responses of the two groups to the statement 'Consumers understand the meaning of ecolabels'. This result was also found for each of the subsectors.

The result that labeled firms tend to agree more strongly with the statement 'There is sufficient assessment of compliance of labeled firms with ecolabel's rules' than unlabeled firms seems to hold for all of the subsectors except for the conference centres. The non-significance for conference centres can be explained by the sample size: only four unlabeled conference centres responded to this statement.

\subsection{Econometric Analysis}

The previous section presented the results of one-way statistical tests. In this section, we present results of a multiple regression analysis. We use probit and logit models to analyze which variables affect the likelihood of having adopted the Green Key ecolabel. The dependent variable takes a value of one if the firm adopted the Green Key ecolabel and the value of zero if it had not (we excluded the dummy variable for location in an urban as opposed to rural area, since this question was only asked to firms with a single establishment). The independent variables included are those that showed statistically significant differences between labeled and unlabeled firms in the one-way statistical analyses above. For firm characteristics, these are age, size (one of the reported proxies), sector, and whether the respondent (strongly) agreed with the statement that sustainability was important for the company, were we used the natural logarithm of $(1+$ age $)$ to decrease the skewness of the data and avoid having to take the logarithm of zero. We have not reported the results for size in terms of number of FTE, since the number of observations was too low for the regression results to be meaningful. For market conditions, we included one of two proxies for the number of competitors that had an 
ecolabel: a dummy equal to one when the respondent strongly disagreed with the statement that many competitors had an ecolabel, or the reported percentage of competitors that had an ecolabel. Here we used "(strongly) disagree" because "(strongly) agree" has zero respondents without the Green Key label. We use the natural logarithm of $(1+$ reported percentage) for the percentage of competitors with an ecolabel to decrease the skewness of the data and avoid having to take the logarithm of zero. In addition we included a dummy variable that was equal to one when the respondent (strongly) agreed with the statement that customers valued sustainability. For the perceptions of ecolabels (of firms and of customers), we included a dummy variable that was equal to one when the respondent (strongly) agreed with the statement that there was sufficient assessment of compliance of labeled firms, and a dummy that was equal to one when the respondent (strongly) agreed with the belief that customers were confident that the information conveyed by ecolabels was reliable.

To facilitate interpretation of the regression results, Table 9 reports marginal effects (average marginal effects over all the observations), which were calculated based on the results from the probit and logit estimations, instead of coefficients from the regressions. Column (1) presents results for a probit model. The probability of having adopted the Green Key label was 0.367 higher for firms with multiple establishments (a proxy for firm size) than for firms with a single establishment, controlling for all of the covariates. The marginal effect for age shows that a $10 \%$ increase in age increases the probability of having adopted the Green Key label by 7\%. Firms in the sectors Hotels and B \& Bs, Campsites, and Holiday villages and group accommodations had a probability of being labeled that was about 0.3 lower than the Conference centers sector. We could not reject the null hypothesis that the probability was identical for the former three sectors $(p=0.75)$. Regarding variables that describe market conditions: firms that (strongly) disagreed with the statement that many competitors had an ecolabel were $20 \%$ less likely to adopt the Green Key label than firms that were neutral toward the statement or (strongly) agreed, and firms that (strongly) agreed with the statement that sustainability was important for their company were 39\% more likely to have adopted the label than their peers. Perceptions of customers' attitudes toward ecolabels did not seem to be correlated with the probability of having adopted the Green Key label, whereas having (strongly) agreed with the statement that labeled firms were sufficiently assessed was positively correlated with ecolabel adoption (probability of having adopted was 0.4 higher).

In columns (2)-(4), we report the results of sensitivity analyses. In column (2), we present results for a logit regression model instead of a probit model. The results were nearly identical. The results in column (3) are based on a probit model with four revenue categories as proxies for size rather than a dummy for having multiple establishments (note that this regression has fewer observations). The reference group has revenues of less than $€ 100,000$. Larger firms were $19-26 \%$ more likely to have adopted the Green Key label. While the probability of adoption for the largest firms cannot be statistically distinguished from that of the smallest firms, it also did not differ statistically from the firms with revenues ranging from 0.5 to 1.5 million euros. All the other results were close to those in column (1), except for one: the probability of adoption for Campsites did not differ statistically from that of the Conference centres sector. For the results in column (4), we replaced the dummy for strongly disagreeing with the statement that many competitors had an ecolabel by the logarithm of the reported percentage of competitors that had an ecolabel. A 10\% increase in the perceived percentage of labeled competitors increased the probability of adoption by $6.6 \%$, which confirmed that perceptions of competitors having a label were positively correlated with the probability of having adopted the Green Key label. All the other results were close to those in column (1), except for a positive correlation between (strongly) agreeing with the statement that consumers valued sustainability and Green Key adoption, which was statistically significant. Finally, in column (5), we present results for a regression without potentially endogenous independent variables. Again, size and age were positively correlated with adoption, and the Conference centres sector had a higher probability of adoption than the other sectors. In addition, the firms that (strongly) disagreed with the statement that many competitors had an eco-label were less likely to have adopted the Green Key label, as in the other regressions. 
Table 9. Marginal effects from probit and logit regressions.

\begin{tabular}{|c|c|c|c|c|c|}
\hline $\begin{array}{c}\text { Dependent: Has Green Key } \\
\text { label }(\text { Yes }=1)\end{array}$ & (1) & (2) & (3) & (4) & (5) \\
\hline & Probit & Logit & Probit & Probit & Probit \\
\hline Multiple & $\begin{array}{c}0.367^{* * * *} \\
(0.05)\end{array}$ & $\begin{array}{c}0.366^{* * *} \\
(0.05)\end{array}$ & & $\begin{array}{l}0.314^{* * *} \\
(0.06)\end{array}$ & $\begin{array}{l}0.412 * * * \\
(0.13)\end{array}$ \\
\hline Age & $\begin{array}{c}0.072 * * \\
(0.03)\end{array}$ & $\begin{array}{l}0.071^{* *} \\
(0.03)\end{array}$ & $\begin{array}{l}0.061 * \\
(0.03)\end{array}$ & $\begin{array}{c}0.081^{* * *} \\
(0.03)\end{array}$ & $\begin{array}{c}0.097^{* * *} \\
(0.04)\end{array}$ \\
\hline $\begin{array}{l}\text { Hotel and } \\
\text { B \& B }\end{array}$ & $\begin{array}{c}-0.282^{* * *} \\
(0.09)\end{array}$ & $\begin{array}{c}-0.290^{* *} \\
(0.12)\end{array}$ & $\begin{array}{c}-0.236^{* *} \\
(0.11)\end{array}$ & $\begin{array}{c}-0.268^{* *} \\
(0.12)\end{array}$ & $\begin{array}{c}-0.451^{* * *} \\
(0.11)\end{array}$ \\
\hline Campsite & $\begin{array}{c}-0.320 * * * \\
(0.09)\end{array}$ & $\begin{array}{c}-0.330^{* * * *} \\
(0.12)\end{array}$ & $\begin{array}{c}-0.169 \\
(0.12)\end{array}$ & $\begin{array}{c}-0.367^{* * *} \\
(0.11)\end{array}$ & $\begin{array}{c}-0.363^{* * *} \\
(0.11)\end{array}$ \\
\hline $\begin{array}{l}\text { Holiday vill. } \\
\text { and group acc. }\end{array}$ & $\begin{array}{c}-0.338^{* * *} \\
(0.10)\end{array}$ & $\begin{array}{c}-0.336^{* * *} \\
(0.13)\end{array}$ & $\begin{array}{c}-0.213 * \\
(0.12)\end{array}$ & $\begin{array}{c}-0.328^{* * *} \\
(0.12)\end{array}$ & $\begin{array}{c}-0.322^{* * *} \\
(0.12)\end{array}$ \\
\hline Disagr. Many & $-0.197^{* * *}$ & $-0.188^{* * *}$ & $-0.230^{* * *}$ & & $-0.268^{* * *}$ \\
\hline labelled Competitors & $(0.06)$ & $(0.06)$ & $(0.06)$ & & $(0.08)$ \\
\hline $\begin{array}{l}\text { Sustainability } \\
\text { important }\end{array}$ & $\begin{array}{l}0.388^{* * *} \\
(0.05)\end{array}$ & $\begin{array}{l}0.392^{* * *} \\
(0.05)\end{array}$ & $\begin{array}{l}0.358^{* * *} \\
(0.06)\end{array}$ & $\begin{array}{l}0.401^{* * *} \\
(0.05)\end{array}$ & \\
\hline Cons. value & 0.057 & 0.053 & 0.058 & $0.112^{* *}$ & \\
\hline sustainability & $(0.05)$ & $(0.05)$ & $(0.06)$ & $(0.05)$ & \\
\hline Consumers & 0.008 & 0.013 & 0.042 & 0.013 & \\
\hline confident & $(0.05)$ & $(0.06)$ & $(0.07)$ & $(0.06)$ & \\
\hline Firms & $0.402^{* * *}$ & $0.399^{* * *}$ & $0.368^{* * *}$ & $0.319^{* * *}$ & \\
\hline assessed & $(0.06)$ & $(0.06)$ & $(0.06)$ & $(0.06)$ & \\
\hline Revenue & & & $0.187^{* *}$ & & \\
\hline $100-500 K$ & & & $(0.08)$ & & \\
\hline Revenue & & & $0.255^{* * *}$ & & \\
\hline 500-1500K & & & $(0.09)$ & & \\
\hline Revenue & & & 0.185 & & \\
\hline$>1500 \mathrm{~K}$ & & & $(0.12)$ & & \\
\hline $\begin{array}{l}\% \text { competitors } \\
\text { with label }\end{array}$ & & & & $\begin{array}{c}0.066^{* * *} \\
(0.02)\end{array}$ & \\
\hline Log-likelih. & -40.449 & -40.825 & -30.517 & -29.087 & -75.008 \\
\hline $\mathrm{Chi}^{2}$ & 75.538 & 59.181 & 81.286 & 71.241 & 39.33 \\
\hline Pseudo- $R^{2}$ & 0.574 & 0.570 & 0.599 & 0.633 & 0.251 \\
\hline $\mathrm{N}$ & 138 & 138 & 111 & 115 & 146 \\
\hline
\end{tabular}

$* \overline{p<0.1, * * p<0.05, * * * p<0.01 \text {; Huber-White robust standard errors in parentheses. Model statistics from }}$ underlying probit/logit model.

\section{Discussion}

To our knowledge, the results from the literature on ecolabels mostly focus on motivations and perceptions rather than firm characteristics, market conditions, and perceptions of ecolabels. Consequently, most references in this section refer to the EMS literature.

We find that labeled hotels and B \& Bs are larger than their unlabeled counterparts, which is in line with findings by Segarra-Oña et al. [7] for the ISO14001 adoption by Spanish hotels. However, our results are mixed for the other subsectors, where labeled firms tended to be larger in terms of revenues, but not in terms of the number of establishments, and only labeled holiday villages and group accommodations were larger than their unlabeled competitors in terms of employees. Although the sustainable entrepreneurship literature [31] suggests that smaller and younger firms stimulate disruptive sustainability innovation, we found that firms with the Green Key label were not smaller, and tended to be older. This might be due to the low innovative character of the sustainable measures that are necessary to obtain the label, such as water and energy reduction and offering sustainable food and beverages. Labeled firms tend to have more establishments than unlabeled firms, which is in line with the findings of Álvarez Gil et al. [29] and Ayuso [23] for EMSs. Ayuso [23] found that staff involvement is critical for the implementation of an EMS in hotels, which suggests that smaller 
hotels are more likely to adopt sustainable business practices. Our result that labeled hotels are larger than their unlabeled competitors suggests that either larger firms are able to involve their staff, or staff involvement is less important than previously thought (perhaps because being well-organized is more important than the involvement of individual staff members).

We find that labeled hotels and B \& Bs are more likely to be located in urban areas than their unlabeled competitors. This is contrary to the findings of Segarra-Oña et al. [7] for ISO14001 adoption by hotels.

The two groups of firms did not differ in their response to the statement 'Consumers understand the meaning of ecolabels'. Interestingly, not a single firm responded 'strongly agree', and for both groups of firms, a large share responded 'disagree' or 'strongly disagree'. This is in line with earlier findings that consumers are unfamiliar with or sceptical toward certification schemes [6,15]. Hotels and B \& Bs seemed to be the only sector in which labeled firms tended to agree more strongly with the statement that consumers are confident that the information conveyed by ecolabels is reliable. Again, this result shows that whereas most of the research on ecolabel adoption in the tourism sector focuses on the Hotel and B \& B sector, the results for this sector are not necessarily representative for other subsectors of the accommodation sector.

Multiple regression analysis confirmed the results of the statistical tests for most of the variables. However, the correlation between adoption and firms' perceptions of consumers' opinions on sustainability and reliability of ecolabels largely disappeared in the regression analysis.

\section{Conclusions}

The economics literature on ecolabel adoption hypothesizes that using green production technologies leads to higher production costs and requires a higher price. The tourism literature-often using small samples of firms that are not randomly selected-finds that ecolabel adoption tends to lead to lower costs. Using a large, randomly selected sample of firms confirms the results from the tourism literature: labeled firms on average faced a reduction in costs, but did not increase their price.

The tourism literature on ecolabel adoption focuses on the Hotel and B \& B sector. We extended this by including campsites and group accommodations. Our results for hotels and B \& Bs only partially confirmed the findings from the literature. In addition, we found that the results for this subsector of the accommodation sector are not representative for other subsectors: campsites, holiday villages and group accommodations, and conference centers. We found that hotels and B \& Bs with the Green Key label tended to be larger than unlabeled competitors. Labeled companies in all the subsectors of the accommodation sector tended to have more revenues and, apart from Campsites, more employees (in FTE). Labeled hotels and B \& Bs also tended to have more establishments than unlabeled competitors. These results suggest that economies of scale (for example, resulting in the availability of monetary and non-monetary resources, or being able to apply the same assessment procedure to multiple establishments) matter for ecolabel adoption. While the age distribution of firms in the Hotel and B \& B sector did not seem to differ for labeled and unlabeled firms, labeled firms in the other subsectors tended to be older than unlabeled firms. Labeled firms reported a higher number for the percentage of competitors with an ecolabel than unlabeled firms did. However, it does not seem that labeled firms operate in a business environment in which competition focuses on having a 'green image'.

Adoption of the Green Key label and implementing sustainable business practices led to a reduction in costs for $58 \%$ or respondents with an average cost reduction of $3.2 \%$. Furthermore, almost $40 \%$ of respondents indicated that they had to make investments of $€ 500$ or less to meet the Green Key requirements. Green Key offers potential adopters the opportunity of opening a test account for a free self-assessment so that firms can get an impression of the efforts to be made to obtain the label. To expand the adoption of its label, Green Key could communicate the opportunity for a free self-assessment and that fulfilling the criteria can lead to permanent cost savings, possibly at relatively low investment costs, more clearly to potential adopters. 
A limitation of this study is that we cannot assess causality. For example, Green Key-labeled firms tended to agree more strongly with the statement 'There is sufficient assessment of compliance of labeled firms with ecolabel's rules' than unlabeled firms. However, whether this was already the case before adoption, or labeled firms became confident due to their experience with the Green Key assessment procedure, cannot be assessed with our data. Another limitation is that not all the surveys were fully completed. Response rates were lower for questions toward the end of the survey, which probably had less to do with fatigue (the median completion time was $7 \mathrm{~min}$ ) and more with the questions at the end being the more sensitive ones (e.g., on profits and turnover). Indeed, in an earlier pilot of the survey, these questions were at the start of the survey, and companies were very reluctant to participate in the survey at all.

In this paper, we focused on ecolabel adoption. Obviously, adoption of the label does not necessarily imply that labeled firms improved their environmental outcomes to comply with the label's standards. As noted, firms may decide to adopt the label because they were already compliant with its standards. Therefore, the question of the label's effects on environmental outcomes is an interesting path for future research. Another interesting question is whether the presence of labeled competitors induces firms to implement sustainable business practices without adopting the label, thereby possibly reducing costs without having to spend money on certification and annual fees. Third, while we found evidence for a profit increase and a cost decrease after adoption, and most respondents were not able to increase their price, we did not assess changes in turnover and occupancy rates. Finally, the potential role of ecolabels in the sharing economy would be interesting to assess. Can ecolabels be expanded to private apartments such that they can be advertised on sharing websites such as AirBnB, and what would be the costs and benefits for the suppliers, customers, and local communities?

Author Contributions: Formal analysis, E.B.; Investigation, E.B. and E.v.d.W.; Methodology, E.B. and E.v.d.W.; Writing-original draft, E.v.d.W.; Writing—review and editing, E.B. and E.v.d.W.

Funding: This research received no external funding.

Acknowledgments: We thank Erik van Dijk, managing director of Green Key Netherlands, for providing us with additional information on Green Key's requirements and implementation, and Mohammed B. Degnet for useful comments on an earlier draft.

Conflicts of Interest: The authors declare no conflict of interest.

\section{Appendix A Survey Response and Descriptive Statistics}

Section 3.2 provides a brief description of our sample. Here, we provide some more details.

As noted in Section 3.2, 206 unique respondents started the questionnaire and at least indicated whether they had the Green Key label. Table A1 shows the response rate (column N) per variable. Note that many variables are categorical variables (e.g., province and Likert-scale questions with the scale ranging from 1 , 'strongly agree', to 5 , 'strongly disagree').

The first block in Table A1 shows the response rate to the questions that we used to check our sample: the province in which the firm is located (see Section 3.2), the sector in which it operates (see Section 3.2), whether it is familiar with the Green Key ecolabel, whether the firm has an ecolabel, and if so, which ecolabel. All the firms that had an ecolabel had the Green Key ecolabel and were familiar with it.

The second block of variables contained the reasons (not) to adopt an ecolabel. See Section 4.1 of the main text.

The third block presents response rates and descriptive statistics for the variables used in Section 4.2. Note that these questions only apply to firms that possess the Green Key ecolabel, i.e., the sample could not be larger than 89 . Since these questions refer to the firm's finances, respondents were reluctant to respond to these questions. Only 57 firms were willing to indicate the size of their investment to obtain the label, and only 71 firms were willing to indicate whether their variable costs increased, decreased, or had stayed the same after adoption. Of these, 25 firms were willing to assign a (non-zero) value to 
the percentage change in variable costs. Of the 89 labeled firms, 69 were willing to indicate whether they had become more profitable after adoption and whether they had been able to ask a higher price.

The final block of variables in Table A1 presents the descriptive statistics of the variables used in the statistical and econometric analyses of Sections 4.3 and 4.4.

The median time used to complete the survey was $7 \mathrm{~min}$. Since some respondents took a break during the survey, the average time was $31 \mathrm{~min}$. The response rate was lower for questions toward the end of the survey. Overall, $13 \%$ of contacted firms completed the survey, and $22 \%$ indicated at least whether they had an ecolabel and some additional information. While the $22 \%$ response rate was lower than average for unannounced online surveys of managers [41], lower response rates for questions toward the end of the survey were not [42] Response rates were lower for questions toward the end of the survey, which probably had less to do with fatigue (given the median completion time of $7 \mathrm{~min}$ ) and more with the questions at the end being the more sensitive ones (e.g., on profits and turnover). Indeed, in an earlier pilot of the survey, these questions were at the start of the survey, and companies were very reluctant to participate in the survey at all.

Table A1. Descriptive statistics.

\begin{tabular}{|c|c|c|c|c|c|}
\hline & $\mathbf{N}$ & Mean & $\begin{array}{l}\text { Std. } \\
\text { Dev. }\end{array}$ & Min. & Max. \\
\hline Province & 193 & 6.91 & 3.39 & 1 & 12 \\
\hline Sector & 205 & 4.33 & 2.84 & 1 & 9 \\
\hline Know Green Key $(\mathrm{Y} / \mathrm{N})$ & 206 & 0.65 & 0.48 & 0 & 1 \\
\hline Has ecolabel $(\mathrm{Y} / \mathrm{N})$ & 206 & 0.43 & 0.49 & 0 & 1 \\
\hline Which ecolabel (GK/other) & 89 & 1.00 & 0.00 & 0 & 1 \\
\hline Reason label & 70 & 2.61 & 1.81 & 1 & 6 \\
\hline Reason no label & 98 & 4.79 & 2.16 & 1 & 7 \\
\hline Investment $(€)$ & 57 & 17,324 & 52,006 & 0 & 350,000 \\
\hline Variable costs up/down/same & 71 & 2.17 & 0.58 & 1 & 3 \\
\hline Variable costs up (\%) & 5 & 10.00 & 3.53 & 5.00 & 15.00 \\
\hline Variable costs down (\%) & 20 & 14.40 & 21.27 & 0.00 & 100.00 \\
\hline More profitable $(\mathrm{Y} / \mathrm{N})$ & 69 & 1.74 & 0.44 & 1 & 2 \\
\hline Higher price $(\mathrm{Y} / \mathrm{N})$ & 69 & 1.96 & 0.20 & 1 & 2 \\
\hline Employees (FTE, log) & 97 & 1.51 & 1.28 & 0.00 & 5.44 \\
\hline Revenue ( 5 categories) & 119 & 2.08 & 1.19 & 1 & 5 \\
\hline Multiple (Y/N) & 206 & 0.07 & 0.26 & 0 & 1 \\
\hline Age (years, log) & 206 & 3.01 & 1.02 & 0.00 & 5.17 \\
\hline Sustainability important for company (5 categories) & 151 & 1.86 & 0.76 & 1 & 4 \\
\hline $\operatorname{Urban}(\mathrm{Y} / \mathrm{N})$ & 191 & 0.16 & 0.36 & 0 & 1 \\
\hline Consumers value sustainability ( 5 categories) & 150 & 2.85 & 0.78 & 1 & 5 \\
\hline Competition_point (4 cat) & 151 & 2.01 & 1.06 & 1 & 4 \\
\hline Many competitors have ecolabel (5 categories) & 149 & 3.44 & 0.98 & 1 & 5 \\
\hline Percentage competitors with label (\%) & 122 & 23.62 & 27.51 & 0.00 & 100.00 \\
\hline Consumers understand (5 categories) & 146 & 3.41 & 0.78 & 2 & 5 \\
\hline Consumers confident ( 5 categories) & 147 & 2.31 & 0.68 & 1 & 5 \\
\hline Assessment of compliance (5 categories) & 148 & 2.55 & 0.75 & 1 & 5 \\
\hline
\end{tabular}

\section{References}

1. Hindle, R.; Swift, J.; Bennett, A.; Macdonald, B.; Denman, J.; Denman, R.; Somper, C. Mapping of Evidence and Trends in Sustainable Tourism; SQW Consulting: London, UK, 2007.

2. Hunter, C.; Shaw, J. The ecological footprint as a key indicator of sustainable tourism. Tour. Manag. 2007, 28, 46-57. [CrossRef]

3. Gössling, S.; Peeters, P. Assessing tourism's global environmental impact 1900-2050. J. Sustain. Tour. 2015, 23, 639-659. [CrossRef]

4. Buckley, R. Tourism ecolabels. Ann. Tour. Res. 2002, 29, 183-208. [CrossRef] 
5. Dunk, R.M.; Gillespie, S.A.; MacLeod, D. Participation and retention in a green tourism certification scheme. J. Sustain. Tour. 2016, 24, 1585-1603. [CrossRef]

6. Geerts, W. Environmental certification schemes: Hotel managers' views and perceptions. Int. J. Hosp. Manag. 2014, 39, 87-96. [CrossRef]

7. Segarra-Oña, M.; Peiró-Signes, Á.; Verma, R.; Miret-Pastor, L. Does environmental certification help the economic performance of hotels? Evidence from the Spanish hotel industry. Cornell Hosp. Q. 2012, 53, 242-256. [CrossRef]

8. Tzschentke, N.; Kirk, D.; Lynch, P.A. Reasons for going green in serviced accommodation establishments. Int. J. Contemp. Hosp. Manag. 2004, 16, 116-124. [CrossRef]

9. Darby, M.R.; Karni, E. Free competition and the optimal amount of fraud. J. Law Econ. 1973, 16, 67-88. [CrossRef]

10. Font, X. Environmental certification in tourism and hospitality: Progress, process and prospects. Tour. Manag. 2002, 23, 197-205. [CrossRef]

11. Iraldo, F.; Barberio, M. Drivers, barriers and benefits of the EU Ecolabel in European companies' perception. Sustainability 2017, 9, 751. [CrossRef]

12. Rivera, J. Assessing a voluntary environmental initiative in the developing world: The Costa Rican Certification for Sustainable Tourism. Policy Sci. 2002, 35, 333-360. [CrossRef]

13. Bjørner, T.B.; Hansen, L.G.; Russell, C.S. Environmental labeling and consumers' choice-An empirical analysis of the effect of the Nordic Swan. J. Environ. Econ. Manag. 2004, 47, 411-434. [CrossRef]

14. Cason, T.N.; Gangadharan, L. Environmental labeling and incomplete consumer information in laboratory markets. J. Environ. Econ. Manag. 2001, 43, 113-134. [CrossRef]

15. Ayuso, S. Comparing voluntary policy instruments for sustainable tourism: The experience of the Spanish hotel sector. J. Sustain. Tour. 2007, 15, 144-159. [CrossRef]

16. Sampaio, A.R.; Thomas, R.; Font, X. Small business management and environmental engagement. J. Sustain. Tour. 2012, 20, 179-193. [CrossRef]

17. Duglio, S.; Ivanov, S.; Magliano, S.; Ivanova, M. Motivation, costs and benefits of the adoption of the European Ecolabel in the tourism sector: An exploratory study of Italian accommodation establishments. Izv. J. Varna Univ. Econ. 2017, 61, 83-95.

18. Barbulescu, A.; Moraru, A.-D.; Duhnea, C. Ecolabelling in the Romanian seaside hotel industry-Marketing considerations, financial constraints, perspectives. Sustainability 2019, 11, 265. [CrossRef]

19. Green Key. Available online: http://www.greenkey.nl (accessed on 17 February 2019).

20. Green Key. Available online: http://www.greenkey.global/history (accessed on 17 February 2019).

21. Plüss, C.; Zotz, A.; Monshausen, A.; Kühhas, C. Sustainability in Tourism. A Guide through the Label Jungle. Available online: https://destinet.eu/who-who/civil-society-ngos/ecotrans/publications/guide-through-labeljungle-1/ (accessed on 17 May 2019).

22. Green Key. Available online: http://www.greenkey.n1/1/library/download/106681 (accessed on 6 March 2014).

23. Ayuso, S. Adoption of voluntary environmental tools for sustainable tourism: Analyzing the experience of Spanish hotels. Corp. Soc. Responsib. Environ. Manag. 2006, 13, 207-220. [CrossRef]

24. Mason, C.F. The economics of eco-labeling: Theory and empirical implications. Int. Rev. Environ. Resour. Econ. 2012, 6, 341-372. [CrossRef]

25. Garay, L.; Font, X. Doing good to do well? Corporate social responsibility reasons, practices and impacts in small and medium accommodation enterprises. Int. J. Hosp. Manag. 2012, 31, 329-337. [CrossRef]

26. Vernon, J.; Essex, S.; Pinder, D.; Curry, K. The "greening" of tourism micro-businesses: Outcomes of focus group investigations in South East Cornwall. Bus. Strategy Environ. 2003, 12, 49-69. [CrossRef]

27. Ateljevic, J. Small tourism firms and management practices in New Zealand: The centre stage macro region. Tour. Manag. 2007, 28, 307-316. [CrossRef]

28. Brammer, S.; Hoejmose, S.; Marchant, K. Environmental management in SMEs in the UK: Practices, pressures and perceived benefits. Bus. Strategy Environ. 2012, 21, 423-434. [CrossRef]

29. Álvarez Gil, M.J.; Burgos Jiménez, J.; Céspedes Lorente, J.J. An analysis of environmental management, organizational context and performance of Spanish hotels. Omega Int. J. Manag. Sci. 2001, 29, 457-471. [CrossRef]

30. Carmona, E.; Céspedes, J.; De Burgos, J. Environmental strategies in Spanish hotels: Contextual factors and performance. Serv. Ind. J. 2004, 24, 101-130. [CrossRef] 
31. Hockerts, K.; Wüstenhagen, R. Greening Goliaths versus emerging Davids-Theorizing about the role of incumbents and new entrants in sustainable entrepreneurship. J. Bus. Ventur. 2010, 25, 481-492. [CrossRef]

32. Griliches, Z. Hybrid corn: An exploration in the economics of technical change. Econometrica 1957, 48, 501-522. [CrossRef]

33. Sipic, T. Eco-labelling of marine recreation services: The case of Blue Flag price premium in Croatia. J. Ecotour. 2017, 16, 1-23. [CrossRef]

34. Chen, Y.S.; Chang, C.H. Greenwash and green trust: The mediation effect of green consumer confusion and green perceived risk. J. Bus. Ethics 2013, 114, 489-500. [CrossRef]

35. Gössling, S.; Buckley, R. Carbon labels in tourism: Persuasive communication? J. Clean. Prod. 2016, 111, 358-369.

36. Mufidah, I.; Jiang, B.C.; Lin, S.-C.; Chin, J.; Puspa Rachmaniati, Y.; Fadil Persada, S. Understanding the consumers' behavior intention in using green ecolabel product through pro-environmental planned behavior model in developing and developed regions: Lessons learned from Taiwan and Indonesia. Sustainability 2018, 10, 1423. [CrossRef]

37. Duglio, S.; Beltramo, R. Quality assessment in the Italian mountain huts. Eur. J. Tour. Res. 2014, 8, 115-142.

38. Font, X.; Sanabria, R.; Skinner, E. Sustainable tourism and ecotourism certification: Raising standards and benefits. J. Ecotour. 2003, 2, 213-218. [CrossRef]

39. Green Key. Available online: http://www.greenkey.nl/locaties (accessed on 12 February 2014).

40. Kamer van Koophandel. Available online: http://www.kvk.nl (accessed on 12 February 2014).

41. Cycyota, C.S.; Harrison, D.A. What (not) to expect when surveying executives: A meta-analysis of top manager response rates and techniques over time. Organ. Res. Methods 2006, 9, 133-160. [CrossRef]

42. Flynn, A. e-Surveying and respondent behaviour: Insights from the public procurement field. Electron. J. Bus. Res. Methods 2018, 16, 38-53.

(C) 2019 by the authors. Licensee MDPI, Basel, Switzerland. This article is an open access article distributed under the terms and conditions of the Creative Commons Attribution (CC BY) license (http://creativecommons.org/licenses/by/4.0/). 